\title{
OUTPLANTING PERFORMANCE OF EUCALYPTUS CLONAL CUTTINGS PRODUCED IN DIFFERENT CONTAINERS AND SUBSTRATES ${ }^{1}$
}

Teresa Aparecida Soares de Freitas ${ }^{2}$, Deborah Guerra Barroso ${ }^{3}$, José Geraldo de Araújo Carneiro ${ }^{3}$, Ricardo Miguel Penchel ${ }^{4}$ e Marcos Pellegrini Coutinho ${ }^{5}$

\begin{abstract}
The objective of this work was to evaluate the outplanting growth of Eucalyptus grandis e E. saligna clones, produced by cuttings in tubes $\left(50 \mathrm{~cm}^{3}\right)$ and in pressed blocks $(40 \times 60 \times 07 \mathrm{~cm})-175 \mathrm{~cm}^{3} /$ seedlings, with different substrates (BT - sugarcane bagasse+sugarcane filter cake; AR - carbonized rice hull + eucalyptus bark; TF - peat). The experiment was arranged in a randomized block design, in a $2 \times 7$ factorial ( 2 clones and 7 treatments), with four replicates with 25 plants. Survival was evaluated two months later. Plant growth was monitored through height and ground level diameter at 20,40, 60, 120 and 180 days after outplanting. To evaluate the effect of the containers on stem and root biomass in both clones, 180 days after outplanting, the cuttings grown in BT substrate with fertilizer were selected. One plant per plot of each clone, grown in tubes and in pressed blocks was selected. The E. grandis and E. saligna cuttings grown in pressed blocks with sugarcane bagasse+sugarcane filter cake presented greater height and diameter after out planting. Both clones presented larger root, bark, log and branch biomass production in plants produced in the block system. Cuttings of E. saligna grown in pressed blocks showed $80 \%$ most wood biomass 180 days after outplanting, compared to that grown in tubes. In E. grandis, the differences in diameter and height, in function of the cutting production system, decreased along time, while in E. saligna these differences increased along the evaluation period.
\end{abstract}

Keywords: Root deformation, biomass and cuttings.

\section{DESEMPENHO PÓS-PLANTIO DE MUDAS CLONAIS DE EUCALIPTO PRODUZIDAS EM DIFERENTES RECIPIENTES E SUBSTRATOS}

\begin{abstract}
RESUMO - O objetivo deste trabalho foi avaliar o crescimento no campo dos clones de Eucalyptus grandis e E. saligna, originadas de miniestacas produzidas em tubetes $\left(50 \mathrm{~cm}^{3}\right)$ e em blocos prensados $(40 \times 60$ $x 07 \mathrm{~cm})-175 \mathrm{~cm}^{3} / \mathrm{muda}$, com diferentes substratos (BT-bagaço de cana-de-açúcar+torta de filtro de usina de cana-de-açúcar; AR - casca de eucalipto decomposta +casca de arroz carbonizada; TF-turfa). Foi utilizado um delineamento em blocos casualizados, em esquema fatorial $2 \times 7$ ( 2 clones e 7 tratamentos), com quatro repetições de 25 mudas. A porcentagem de sobrevivência foi avaliada dois meses após o plantio. A altura e diâmetro ao nível do solo foram monitorados aos 20, 40, 60 e 180 dias após o plantio. Para avaliar o efeito dos recipientes sobre a biomassa aérea e radicular de ambos os clones, 180 dias após o plantio as mudas produzidas em substrato BT com adubação foram selecionadas. Foi selecionada uma planta por parcela de cada clone, produzidas em tubetes e blocos. As mudas de $\boldsymbol{E}$. grandis e E. saligna produzidas em blocos prensados em bagaço de cana-de-açúcar+torta de filtro de cana-de-açúcar apresentaram maior
\end{abstract}

\footnotetext{
${ }^{1}$ Recebido em 02.07.2007 e aceito para publicação em 22.08.2008.

${ }^{2}$ Departamento de Engenharia Florestal da Universidade Federal do Recôncavo da Bahia (UFRB). E-mail: <tas_freitas@ @otmail.com>.

${ }^{3}$ Universidade Estadual do Norte Fluminense, Campos dos Goytacazes-RJ. E-mail: <carneiro@uenf.br>; <deborah@uenf.br>.

${ }^{4}$ Pesquisador da Aracruz Celulose, PhD. E-mail: <rp@aracruz.com.br>.

${ }^{5}$ Ministério do Meio Ambiente, Secretaria de Biodiversidade e Florestas, Brasília-DF. E-mail: <marcos.coutinho@mma.gov.br>.
} 


\begin{abstract}
crescimento em altura e diâmetro após o plantio. Em ambos os clones foi observada maior produção de biomassa de raiz, casca, lenho e galhos nas plantas produzidas em sistemas de blocos prensados. As mudas de $\boldsymbol{E}$. saligna produzidas em blocos prensados apresentaram cerca de $80 \%$ a mais de lenho, 180 dias após o plantio, em relação às plantas provenientes de mudas produzidas em tubetes. No E. grandis, as diferenças em diâmetro e altura, em função do sistema de produção, foram reduzidas ao longo do tempo, enquanto no $\boldsymbol{E}$. saligna essas diferenças foram acentuadas ao longo do período de avaliação.
\end{abstract}

Palavras-chave: Deformação de raízes, biomassa e mudas.

\section{INTRODUCTION}

The root system of the plants constitutes a component of fundamental importance in the soil, once it represents the main source of organic matter, affecting simultaneously, the microbial activity of the soil and the decomposition process (CHENG, 1999).

The seedlings should be planted with a minimum of disturbances and exhibition of the root system, to reduce the planting stress and to increase the survival and the growth in the field (TINUS and MCDONALD, 1979).

According to Barnett (1983), the growth in the field is higher, as the dimensions of the seedlings are larger at the planting season. The restriction of the root system in the nursery limits the growth, such as the reduction of the leaf area, height and biomass production (REIS et al., 1989; TOWNEND and DICKINSON, 1995).

Some authors demonstrated that the substrate quality and seedlings when grown under root restrictive system show serious root deformations after the planting and lower rates of initial growth in the field. (NOVAES, 1998; BARROSO et al., 2000c). The high initial growth rate after the planting is of high economical importance in the establishment of forests, as it can reduce the cost of weeds control.

According to Carneiro (1987), the containers should not cause folds, estrangulation and spiral deformations to the roots. Their material should not decompose in the nursery and they should hold enough volume of substrate to support the needs of the species. Small containers not only cause root deformations, but also limit the supply of nutrients and water to the seedlings. However, containers with big diameter and high volume of substrate cause unnecessary expenses, enlarge the area of the nursery and increase transport costs, (GOMES et al., 1990, CARNEIRO, 1995).

R. Árvore, Viçosa-MG, v.32, n.6, p.1019-1028, 2008
Small tubes with low substrate volume to grow Eucalyptus seedlings, demand application of higher doses of nutrients, due to the losses by lixiviation, requiring the need of frequent waterings (NEVES et al., 1990). Another disadvantage in Eucalyptus nurseries are the losses of water and nutrients, during the fertirrigation, due to the new density with larger spacing among the tubes usual practice in the nursery, to promote the cell hardness.

In some foreign countries, the use of perforated wall containers or absence of walls is priorized. In Finland, seedlings grown in peat pressed blocks $(60 \times 40 \times 7$ $\mathrm{cm}$ ) show high potential of regeneration of roots and favorable growth medium due to the absence of root growth restriction (PARVIAINEN, 1990).

Forest seedlings grown in pressed blocks presented good results after the planting (CARNEIRO and PARVIAINEN, 1988; CARNEIROandBRITO, 1992; LELES et al., 2000; NOVAES, 1998; BARROSO et al., 2000c, MORGADO et al., 2000). To the same conclusion came Schiavo e Martins (2002) for fruit trees. However, there is no information regarding the outplanting behavior of Eucalyptus produced by minicuttings in this system.

The objective of this work was to evaluate the survival, growth and outplanting biomass production of Eucalyptus cuttlings, grown in tubes and in pressed blocks, in different substrates with and without fertilization.

\section{MATERIALAND METHODS}

This study was carried out at the Company Aracruz Celulose S.A., in Aracruz, at the coastal area of Espírito Santo State, Brazil, located from $19^{\circ} 48^{\prime} \mathrm{S}$ to $40^{\circ} 17^{\prime} \mathrm{W}$. The precipitation in the experimental period was of $724,9 \mathrm{~mm}$; the average temperature was $24^{\circ} \mathrm{C}$, with a minimum of $20.6^{\circ} \mathrm{C}$ and maximum of $28.8^{\circ} \mathrm{C}$.

The cuttlings of the two clones, of Eucalyptus grandis and E. saligna, were grown in tubes $\left(50 \mathrm{~cm}^{3}\right)$ 
and in pressed blocks (40x60x07 cm), with different substrates. The following substrates were used: 1 ) sugarcane bagasse + sugarcane filter cake- BT, 3:2 $(\mathrm{v}: \mathrm{v}) ; 2)$ rice carbonized hull + eucalyptus bark - AR, 7:3 (v:v);3) peat pressed block, imported from Finland.

The two clones cuttlings were submitted to the following treatments in the nursery: $\mathrm{T} 1$ - tube with the AR substrate and fertilizer; T2 - tube with BT substrate and fertilizer; T3 - tube with BT substrate; T4 - block with the AR substrate and fertilizer; T5 - block with BT substrate and fertilizer; T6 - block with BT substrate; T7 - finnish peat in pressed block. The applied fertilizer was the osmocote ${ }^{\circledR}$ of slow liberation (19-6-10), in the dose of $1,5 \mathrm{~kg} \mathrm{~m}^{-3}$. The characteristics of the substrate are showed in the Tables 1 and 2 .

After the nursery phase, 25 cuttlings of each treatment were outplanted in a $2 \times 7$ factorial randomized block design, with four replications.
The planting was carried out in a Haplic Acrisols (FAO, 1990), flat area with a loamy/clay texture. The area was subsoiled at a depth of $100 \mathrm{~cm}$. In the planting line $500 \mathrm{Kg} \mathrm{ha}^{-1}$ of natural reagent phosphorus was applied.

At the lifting time for the outplanting the characteristics of the cuttlings are shown in Table 3.

In the planting hole were applied $120 \mathrm{~g}$ of $\mathrm{N}$ $\mathrm{P}_{2} \mathrm{O}_{5}-\mathrm{K}_{2} \mathrm{O}(06-30-06)+1 \%$ of $\mathrm{Zn}$. The covering fertilization was carried out after at 100 days, with of the application of $100 \mathrm{~g}$ of $\mathrm{N}-\mathrm{P}_{2} \mathrm{O}_{5}-\mathrm{K}_{2} \mathrm{O}$ (15-00$30)+1 \%$ of $\mathrm{B}$ at the base of each plant, in the projection of the canopy.

Two months later, the survival was evaluated. The growth of the plants was monitored in height and ground level diameter at 20,40,60, 120 and 180 days after the outplanting.

Table 1 - Physical analysis of the substrates: sugarcane bagasse + sugarcane filter cake (BT), carbonized rice hull + Eucalyptus bark (AR) and peat

Tabela 1 - Análise física dos substratos: bagaço de cana-de-açúcar + torta de filtro (BT), casca de arroz carbonizado + casca de eucalipto (AR) e turfa

\begin{tabular}{|c|c|c|c|c|c|c|}
\hline \multirow[t]{3}{*}{ Characteristics } & & \multicolumn{4}{|c|}{ Substrate } & \multirow{3}{*}{$\frac{\text { Peat }}{P}$} \\
\hline & \multirow[t]{2}{*}{ Unit } & \multicolumn{2}{|c|}{$\mathrm{AR}$} & \multicolumn{2}{|c|}{$\mathrm{BT}$} & \\
\hline & & $\mathrm{P}$ & NP & $\mathrm{P}$ & NP & \\
\hline Total porosity & $\mathrm{m}^{3} \mathrm{~m}^{-3}$ & 0,91 & 0,89 & 0,91 & 0,92 & 0,89 \\
\hline Macroporosity & $\mathrm{m}^{3} \mathrm{~m}^{-3}$ & 0,54 & 0,70 & 0,51 & 0,78 & 0,47 \\
\hline Microporosity & $\mathrm{m}^{3} \mathrm{~m}^{-3}$ & 0,36 & 0,18 & 0,40 & 0,15 & 0,42 \\
\hline Apparent Density & $\mathrm{Mg} \mathrm{m}^{-3}$ & 0,26 & 0,32 & 0,21 & 0,19 & 0,13 \\
\hline Real Density & $\mathrm{Mg} \mathrm{m}^{-3}$ & _ & 4,00 & _ & 2,45 & 1,14 \\
\hline
\end{tabular}

The pressed material was obtained after moistening the substrate.

$\mathrm{P}$ - pressed substrate; NP - not pressed substrate.

Table 2 - Chemical analysis of the substrates: sugar cane bagasse + sugar cane filter cake (BT), carbonized rice bark + eucalyptus bark (AR) and peat

Tabela 2 - Análise química dos substratos: bagaço de cana-de-açúcar + torta de filtro de (BT), casca de arroz carbonizado + casca de eucalipto (AR) e turfa

\begin{tabular}{ccccc}
\hline Characteristic & & \multicolumn{2}{c}{ Substrate } \\
\cline { 3 - 5 } & Unit & AR & B T & Peat \\
\hline $\mathrm{CE}$ & $\mu \mathrm{S} \mathrm{cm}^{-1}$ & 1,10 & 1,40 & 0,24 \\
$\mathrm{pH}$ & & 5,61 & 5,36 & 4,60 \\
$\mathrm{~N}$ & $\mathrm{~g} \mathrm{Kg}^{-1}$ & 12,01 & 9,87 \\
$\mathrm{P}$ & $\mathrm{mg} \mathrm{dm}^{-3}$ & 59,77 & 23,780 & 46,14 \\
$\mathrm{~K}$ & $\mathrm{mmol}_{\mathrm{c}} \mathrm{dm}^{-3}$ & 52,35 & 60,07 & 36,00 \\
$\mathrm{~S}$ & $\mathrm{~g} \mathrm{Kg}^{-1}$ & 1,94 & 85,00 & 4,51 \\
$\mathrm{Ca}$ & $\mathrm{mmol}_{\mathrm{c}} \mathrm{dm}^{-3}$ & 41,00 & 3,67 & 55,5 \\
$\mathrm{Mg}$ & $\mathrm{mmol}_{\mathrm{c}} \mathrm{dm}^{-3}$ & 40,44 & 66,92 & 74,53 \\
\hline
\end{tabular}

*N: method of Nessler; S: turbidimety; P and K: extractor of Mehlich-1; Ca and Mg: extractor of KCL $1 \mathrm{M}$. 
Table 3 - Height and root collar diameter of 90 day Eucalyptus cuttlings, at the lifting time Tabela 3 - Altura média e diâmetro de mudas de eucalipto aos 90 dias, no momento de expedição para o campo

\begin{tabular}{lccc}
\hline Treatment & \multicolumn{2}{c}{ Height $(\mathrm{cm})$} & \multicolumn{2}{c}{ Diameter $(\mathrm{mm})$} \\
\cline { 2 - 4 } & E.grandis & E. saligna & 1,98 \\
\hline TUB+AR & 18,59 & 17,66 & 1,98 \\
TUB+BT+A* & 15,67 & 12,32 & 1,70 \\
TUB+BT & 10,37 & 8,37 & 1,44 \\
BL+AR & 18,13 & 18,53 & 1,73 \\
BL+BT+A* & 32,65 & 32,57 & 2,77 \\
BL+BT & 22,02 & 19,59 & 2,05 \\
(BL+Peat & 22,91 & 22,88 & 2,14 \\
\hline
\end{tabular}

* Fertilizer of slow liberation: Osmocote $®(19-6-10) 1,5 \mathrm{~kg}$ substrate $\mathrm{m}^{-3} 1,5 \mathrm{~kg}$ substrate $\mathrm{m}^{-3}$

Substrata: A AR: carbonized rice hull + eucalyptus bark; BT: sugar cane bagasse + sugar cane filter cakes.

With the only objective of evaluating the effect of the containers on the stem and root biomass in the tested clones, 180 days after the outplanting, the treatments that, in the nursery phase, were produced in substrate sugarcane bagasse + filter cake with fertilizer were selected for evaluation. For this evaluation plants were selected with stem diameter in the level of soil in the strip of $\pm 1,0 \mathrm{~cm}$ of the mean of the portion.

The stems were cut at the ground level to measure fresh and dry weights separatedly in the above and below ground level. Also the height and root collar diameter were evaluated. The weights of the leaves, branches, bark, wood were determined as well as the root thickess (thin - up to $0,25 \mathrm{~mm}$; average - 0,26 to 5,0 $\mathrm{mm}$; thick - more than 5,0 $\mathrm{mm}$ ).

To analyse the root archicteture, 180 days after the outplanting, a one meter ray circumference was marked around the collar of each selected plant (one plant for plot). The plants were selected in function of the medium diameter. Carefully at the depth of 80 $\mathrm{cm}$ the root system was pulled out. The number of lateral roots was counted and their malformations (folds, strangulations and spiral form) were transformed into percentage.

Samples of the components of the plants taken from $1 / 3$ of the lower part, $1 / 3$ of the intermediate and $1 / 3$ of the higher part were submitted to $105^{\circ} \mathrm{C}$, during 72 hours in a air forced circular kiln to estimate the dry weights.

The data were submitted to the variance analysis and the averages were compared by test of Tukey (5\%).

\section{RESULTS AND DISCUSSION}

Although high, the survival rate (above 95\%) showed variation among treatments and clones (Table 4). The lowest percentage was observed in the E. saligna outplanting, when the cuttlings were grown in tube with sugarcane bagasse + sugarcane filter cake (TUB+BT). Regarding E.grandis, the lowest value was observed in the same treatment, however with fertilization $(\mathrm{TUB}+\mathrm{BT}+\mathrm{A})$. All survival values are considered high, as the replanting practice is accepted until $10 \%$ (AMBIENTE ..., 2003).

Until 60 days, the plants of all treatments showed the same behavior in height (Figure 1). The highest values were found out when the cuttings were grown in pressed blocks and with sugarcane bagasse + filter cake substrate with fertilization $(\mathrm{BL}+\mathrm{BT}+\mathrm{A})$. The lowest value was observed in the treatment TUB+BT. Cuttlings grown in the same combination, tubes and substrate, presented lower height in the nursery phase, compared to those grown in the block system with the BT substrate (FREITAS, 2003). Leles et al. (2000), Morgado et al. (2000) e Barroso et al. (2000c) also observed lower height in the eucalipt plants 10 months after the outplanting, when grown in tubes.

In relation to the ground level diameter until 40 days, the cuttlings of both clones showed similar answers as the height (Figure 2). Kartelev (1973) observed that the growth immediately after the outplanting depends on the seedling collar diameter and on the growth of the roots in the nursery. Barroso et al. (2000b), Leles et al. (2000) found out those seedlings of Eucalyptus ssp with thicker collar diameter showed higher height 
growth and root dry matter weight. Silva (2003) came to the same conclusion with Coffea canephora.

The effect of the treatments between the clones on the height and diameter of the plants was observed starting from 60 and 40 days, respectively (Figure 1 and 2). The differences in height and diameter $E$. grandis

Table 4 - Survival percentage of Eucalyptus cuttlings grown in the tubes and in pressed blocks with different substrates, 60 days after the outplanting

Tabela 4-Porcentagem de sobrevivência de mudas de eucaliptos produzidas em tubetes e em blocos prensados com diferentes substratos, 60 dias após o plantio

\begin{tabular}{lcc}
\hline Treatment & \multicolumn{2}{c}{ Survival (\%) } \\
\cline { 2 - 3 } & E. grandis & E. saligna \\
\hline TUB+AR & 99,00 a AB & 99,00 a A \\
TUB+BT+A* & $96,00 \mathrm{a} \mathrm{B}$ & 98,00 a A \\
TUB+BT & 100,00 a A & $95,00 \mathrm{~b} \mathrm{~B}$ \\
BL+AR & $97,00 \mathrm{~b}$ AB & 100,00 a A \\
BL+BT+A* & $98,00 \mathrm{~b} \mathrm{AB}$ & 100,00 a A \\
BL+BT & 100,00 a A & 99,00 a A \\
BL+TURFA & 98,00 a AB & 97,00 a AB \\
\hline CV $(\%)$ & \multicolumn{2}{c}{2,71} \\
\hline
\end{tabular}

The same small letter in the lines and capital letters in the columns, don't differ amongst themselves, by Tukey test (5\%).

AR: carbonized rice hull + Eucalyptus bark; BT: sugarcane bagasse + sugar cane filter cake.

* Fertilizer of slow liberation: Osmocote ${ }^{\circledR}(19-6-10) 1,5 \mathrm{~kg} \mathrm{~m}^{-3} \mathrm{de}$ substrate had smaller amplitude compared with $E$. saligna. The plants of $E$. saligna showed in the field a lower height and diameter growth when in the nursery were grown in TUB + BT, as well as those grown in peat pressed blocks (BL + TURFA). For this specie, the largest increment in height and diameter, until 180 days, was obtained in treatment $\mathrm{BL}+\mathrm{BT}+\mathrm{A}$. The same behavior was observed by Freitas (2003), in the nursery phase.

The Table 3 shows that thicker cuttlings of both clones had higher initial growth, as also found out by Barnett (1983); Barroso et al. (2000c); Leles et al. (2000); Morgado et al. (2000) in experiments with different species.

The increment in diameter of E. grandis plants has been reduced along the time. However, this fact was not observed with E. saligna until 180 days after the outplanting (Figure 2). Morgado et al. (2000) also observed this reduction along the time of E. grandis plants when the seedlings were grown in tubes and pressed blocks.

Those differences in the answer among clones, in relation to the treatments, showed that each propagate material needs an appropriate combination of substrate and container, for the good growth after the outplanting, having difference in the sensibility of the species regarding the restriction of root system.


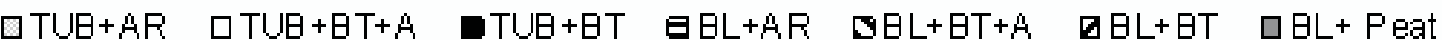

Figure 1 - Height of eucalyptus plants, at different times after planting, originated from stecklings produced in different containers and substrates. (TUB: tube; BL: pressed block; AR: carbonized rice bark + eucalyptus bark; BT: sugarcane bagasse + filter cake; A: Osmocot ${ }^{\circledR}(19-6-10) 1,5 \mathrm{Kg} \mathrm{m}^{-3}$ de substrate).

Figura 1 - Altura de plantas de eucalipto, em diferentes épocas após o plantio, originadas de mudas produzidas em diferentes recipientes e substratos. (TUB: tubete; BL: bloco prensado; AR: casca de arroz carbonizada + casca de eucalipto; BT: bagaço de cana-de-açúcar + torta de filtro; A: Osmocot ${ }^{\circledR}(19-6-10)$ 1,5 $\mathrm{k.g} \mathrm{m}^{-3}$ de substrato) 


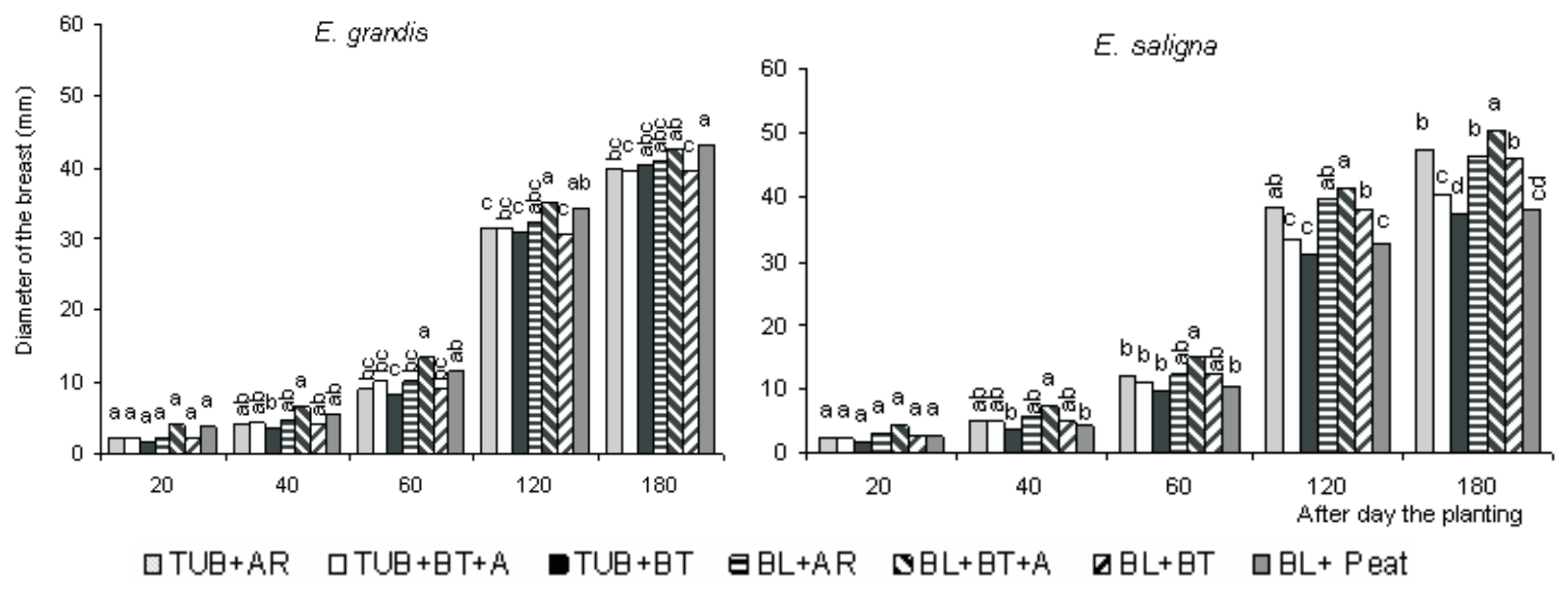

Figure 2 - Collar diameter of eucalyptus plants, at different times after planting, originated of stecklings produced in different containers and substrates. (TUB: tube; BL: pressed block; AR: carbonized rice bark + eucalyptus bark; BT: sugarcane bagasse + filter cake; A: Osmocote ${ }^{\circledR}(19-6-10) 1,5 \mathrm{~kg} \mathrm{~m}^{-3}$ de substrate).

Figure 2 - Diâmetro do colo de plantas de eucalipto, em diferentes épocas após o plantio, originadas de mudas produzidas em diferentes recipientes e substratos. (TUB: tubete; BL: bloco prensado; AR: casca de arroz carbonizada + casca de eucalipto; BT: bagaço de cana-de-açúcar + torta de filtro; A: Osmocot ${ }^{\circledR}$ (19-6-10) 1,5Kg $\mathrm{m}^{-3}$ de substrato).

Leles et al. (2001) also observed that E. grandis showed higher sensibility to root restriction compared with E. camaldulensis seddlings. Those results were not compatible with those found out in this experiment. Reis et al. (1989), Leles et al. (2000) and Moroni et al. (2003), studied different Eucalyptus species, also observed that some of them were more sensitive than others to root restriction.

Although the observed decreasing differences in height and diameter along the time, the initial growth was high enough to reduce the competition with weeds, implying reduction of the cultural clean costs (BARROSO et al., 2000c).

Regarding the plant biomass production of the treatments enveloping tubes and pressed blocks, the E. saligna cuttings showed higher stem weight than E. grandis. However, the cuttlings grown in tubes showed no wood and root biomass difference between the clones (Table 5). Leaf, branch, bark and root biomass have higher gain when the cuttlings were grown in the pressed blocks, except for the thin and average size roots. Regarding production of evaluate biomass among plants, produced in tube and pressed blocks (Table 5), the E. saligna had larger production of aerial biomass than the E. grandis, except in the timber production, for seedlings produced in tube system, where the clones didn't present any difference. In the production of root biomass were not observed differences among clones.

The used technique used for the plant root pulling off could have influenced the absence of differences between the thin $(<0,2 \mathrm{~mm})$ and average sized root $(0,2$ to $0,5 \mathrm{~mm}$ ).

Techniques to quantify precisely the thin roots are of great importance. Such thin roots contributes largely to increase the survival percentage and to the initial growth after the outplanting, even in adverse conditions, through the higher water and nutrient absortion capacity.

Root growth can represent up to $50 \%$ of the primary production, and his is one of the main ways of the carbon uptake by the soil (VOGT and PERSSON, 1991). Pomeroy (1970) arguments that the turnover is essential for the continuity and stability of the live systems. The production of thin roots is a important component for dry matter and for nutrients cycling in the forest ecosystem (SINGH and SINGH, 1981; VOGT et al., 1986; MCCLAUGHERTY et al., 1985).

Both clones presented different behavior regarding the timber dry weight biomass of the cuttings in different systems. The wood production is of major importance. This is the most focused characteristic to select clones to achieve higher wood productivity. 
Table 5 - Biomass of Eucalyptus cuttlings grown in tubetes and pressed blocks, 180 days after the outplanting

Tabela 5 - Biomassa de mudas clonais de eucalipto produzidas em tubetes e blocos prensados, 180 dias após o plantio

\begin{tabular}{|c|c|c|c|}
\hline Component & Treatment & E. grandis & E. saligna \\
\hline$\overline{\text { Bark }}$ & Tubes & $93,81 \mathrm{~b} \mathrm{~B}$ & 113,00 a B \\
\hline \multirow[t]{2}{*}{ (g) } & Blocks & $123,74 \mathrm{~b} \mathrm{~A}$ & 157,47 a $A$ \\
\hline & $\mathrm{CV}(\%)$ & \multicolumn{2}{|c|}{17,1} \\
\hline Leaf & Tubes & $800,51 \mathrm{~b} \mathrm{~A}$ & 1007,77 a $A$ \\
\hline \multirow[t]{2}{*}{ (g) } & Blocks & $955,58 \mathrm{~b} \mathrm{~A}$ & 1218,70 a $A$ \\
\hline & $\mathrm{CV}(\%)$ & \multicolumn{2}{|c|}{16,4} \\
\hline Branch & Tubes & 513,48 b B & 822,18 a B \\
\hline \multirow[t]{2}{*}{ (g) } & Blocks & 627,42 b A & 1031,39 a $\mathrm{A}$ \\
\hline & $\mathrm{CV}(\%)$ & \multicolumn{2}{|c|}{16,4} \\
\hline Wood & Tubes & 398,76 a $\mathrm{A}$ & 400,37 a $B$ \\
\hline (g) & Blocks & $516,64 \mathrm{~b} A$ & 731,90 a $\mathrm{A}$ \\
\hline & $\mathrm{CV}(\%)$ & \multicolumn{2}{|c|}{18,0} \\
\hline \multirow{3}{*}{$\begin{array}{l}\text { Thin roots } \\
(\mathrm{g})\end{array}$} & Tubes & 8,42 a $\mathrm{A}$ & 14,18 a $\mathrm{A}$ \\
\hline & Blocks & 13,49 a $\mathrm{A}$ & 15,14 a $\mathrm{A}$ \\
\hline & $\mathrm{CV}(\%)$ & \multicolumn{2}{|c|}{39,1} \\
\hline Average roots & Tubes & 18,08 a $\mathrm{A}$ & 15,27 a $\mathrm{A}$ \\
\hline \multirow[t]{2}{*}{ (g) } & Blocks & 20,66 a $\mathrm{A}$ & 18,11 a $\mathrm{A}$ \\
\hline & $\mathrm{CV}(\%)$ & \multicolumn{2}{|c|}{22,0} \\
\hline Thick roots & Tubes & 227,23 a $\mathrm{B}$ & 237,39 а $\mathrm{B}$ \\
\hline \multirow[t]{2}{*}{ (g) } & Blocks & 376,58 a A & 497,92 a A \\
\hline & $\mathrm{CV}(\%)$ & \multicolumn{2}{|c|}{20,2} \\
\hline
\end{tabular}

The same small letter in the lines and capital letters in the columns don't differ, by the Tukey test $(5 \%)$.

Cuttlings of E. saligna showed more than $80 \%$ of timber dry biomass when grown in blocks than those grown in the tubes (Table 5). In spite of no significant difference in wood biomass in the cuttlings of $E$. grandis was found out, the plants from the pressed blocks showed almost $30 \%$ more wood than those grown in the tubes, what represents an important gain. These results are alike the behavior of the $E$. grandis regarding the height and the breast diameter (Figures 1 and 2).

Several authors reported that the highest concentration of thin roots is found in the superficial layers of the soil (CARBON et al., 1980; EIS, 1987; MCKAY and MALCOLM, 1988; NOVAES et al., 1990; FITTER, 1991; PERSSON, 1992; MELLO et al., 1998; WITSCHORECK et al., 2003). This also was here verified, but in a visual way, once it was not the objective of the present work to stratify the soil.

A high root emission was observed in both clone cuttlings grown in pressed blocks, but no difference was found out between them. This higher root emission might have been favored by the pruning carried out to the individualization of the cuttlings (Figure 3 ).
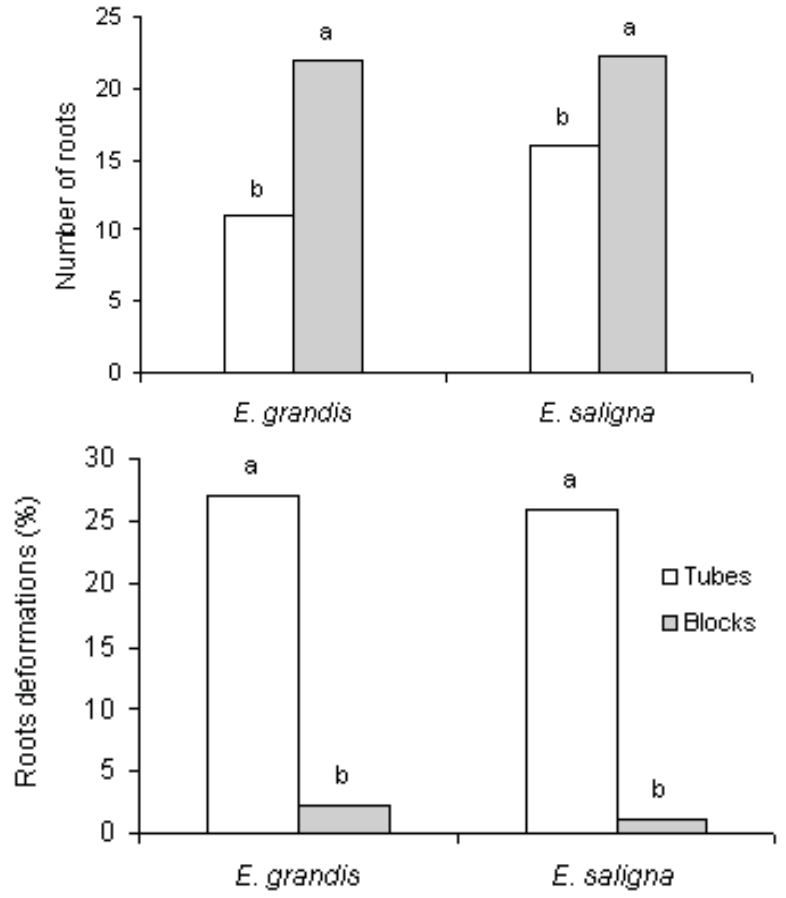

Figure 3- Number of roots emitted from the cut and theirs deformations in eucalyptus clones, 180 days after planting. The stecklings were grown in the tubes and pressed blocks.

Figura 3 -Número de raízes emitidas a partir da estaca e deformações radiculares em clones de eucalipto, aos 180 dias após o plantio. As mudas foram produzidas no sistema de tubetes e blocos prensados.

Reis et al. (1996) verified that the root pruning of Eucalyptus grandis and E. pellita seedlings stimulated a higher root emission and a better root archicteture.

The Figure 3 shows that the cuttlings of both clones presented higher root malformation percentage when grown in tubes. This points out that the root malformations during the growing period in the tubes remained in $30 \%$ of the roots until 180 days after the outplanting. Freitas (2003) also found out that cuttlings of these same clones also grown in tubes and in pressed blocks, two months after transplanted to $20 \mathrm{~L}$ bags also showed malformations reaching $100 \%$ when grown in tubes.

Similar results were found by Schmidt-Vogt (1984), Carneiro (1987), Parvainen and Tervo (1989), Mattei (1993), Barroso et al. (2000c), Morgado et al. (2000), what indicates that rigid walls containers stimulate a high number of roots malformations that remain in the field.

R. Árvore, Viçosa-MG, v.32, n.6, p.1019-1028, 2008 


\section{CONCLUSIONS}

The cuttlings grown in sugarcane bagasse + filter cake blocks pressed blocks showed higher growth rate 180 days after the outplanting, in Eucalyptus saligna and E. grandis.

In both clones, 180 days after the outplanting a higher thick root, bark, wood and branch biomass production was found out, when the seedlings were grown in the pressed blocks. No effect of the containers on the leaf, thin and average diameter root biomass was verified.

Cuttlings of E. saligna grown in pressed blocks showed high wood biomass 180 days after the outplanting.

For Eucalyptus grandis the differences in diameter and height, in function of seedlings production system, are reduced along the time, while for E. saligna these differences were stressed during the evaluation period.

\section{REFERENCES}

AMBIENTE BRASIL. Manejo de

Reflorestamentos. Disponível em: <http:// www.ambientebrasil.com.br/agenda/ imprimir.php?nome=http://www.ambientebra $>$ Acesso em 22 de set. 2003.

BARNETT, J. P. Relating seedling morphology and physiology of container-grown southern pines to field success. In: CONVENTION OF THE SOCIETY OF AMERICAN FORESTERS, 1983, Portland. Proceedings... Portland: USDA. Forest Serv. Southern Forest Experiment Station., 1983. p.405-409.

BARROSO, D. G.; CARNEIRO, J. G. A.; LELES, P. S. S. Qualidade de mudas de Eucalyptus camaldulencis e E. urophylla produzidas em tubetes e em blocos prensados, com diferentes substratos. Floresta e Ambiente, v.7, n.1. p.238-250, 2000a.

BARROSO, D. G. et al. Regeneração de raízes de mudas de eucalipto produzidas em diferentes recipientes e substratos. Scientia Agricola, v.57, n.2, p.229-237, 2000 b.

BARROSO, D. G. et al. Efeitos do recipiente sobre o desempenho pós-plantio de Eucalyptus camaldulensis e E. urophylla. Revista Árvore, v.24, n.3, p.291-296, 2000c.

R. Árvore, Viçosa-MG, v.32, n.6, p.1019-1028, 2008
BÖHM, W. Methods of studying root systems. Berlin: Heidelberg; New York: SpringerVerlag, 1979. 188p.

CARBON, B. A. et al. The distribuition of root length and the limits to flow of soil water to root in a dry sclerophyll forest. Forestry Science, v.26, n.4, p.656-664, 1980.

CARneiro, J. G. A. Produção e controle de qualidade de mudas florestais. Curitiba: UFPR/FUPEF; Campos: UENF, 1995. 451p.

CARNEIRO, J. G. A. Influência de recipientes e de estações de semeadura sobre o comportamento do sistema radicular e dos parâmetros morfológicos de mudas de Pinus taeda e Pinus elliottii. Curitiba: Universidade Federal do Paraná, 1987. 81p.

CARNEIRO, J. G. A.; BRITO, M. A. R. Nova metodologia para a produção mecanizada de mudas de Pinus taeda L. em recipientes com raízes laterais podadas. Floresta, v.22, n.1/2, p.63-77, 1992.

CARNEIRO, J. G. A.; PARVIAINEN, J. V.

Comparison of production methods for containerized pine (Pinus elliottii) seedlings in Southern Brazil. Metsantutkimuslaitoksen Tiedonantoja, v.302, n.1, p.6-24, 1988.

CHENG, W. Rhizosphere feedbacks in elevated $\mathrm{CO}_{2}$. Tree Physiology, v. 19, p.313-320, 1999.

GOMES, J. M. et al. Influência do tamanho da embalagem plástica na produção de mudas de ipê (Tabebuia serratifolia), da copaíba (Copaifera langsdorffii) e de angico-vermelho (Piptadenia peregrina). Revista Árvore, v.14, n.1, p.26-34, 1990.

EIS, S. Root systems of older immature hemlock, Cedar, and Douglas-fir. Canadian Journal Forest Research, v.17, n.11, p.1348-1354, 1987.

FITTER, A. H. Characteristics and functions of root systems. In: WAISEL, Y.; ESHEL, A.; KAFKAFI, U. (Eds) Plant roots; the hidden half. New York: Marcel Dekker, 1991. p.3-25. 
FREITAS, T. A. S. Sistema de blocos prensados para a produção de mudas clonais de eucalipto. 2003. 115f. Dissertação (Mestrado em produção Vegetal) - Universidade Estadual do Norte Fluminense, Campos dos Goytacazes, 2003.

KARTELEV, V. G. Qualitaestsmerkmale des Pflanzenmaterials. Lesnoje Chozjajstvo, v.4, n.1, p.31-33, 1973.

LELES, P. S. S. et al. Crescimento e arquitetura radicial de plantas de Eucalipto oriunda de mudas produzidas em blocos prensados e em tubetes, após o plantio. Cerne, v.7, n.1, p.10-19, 2001.

LELES, P. S. S. et al. Qualidade de mudas de Eucalyptus spp. produzidas em blocos prensados e em tubetes. Revista Árvore, v. 24, n.1, p.13-20, 2000.

MATTEI, V. L. Comparação entre semeadura direta e plantio de mudas produzidas em tubetes, na implantação de povoamentos de Pinus taeda L. 1993. 149f.Tese (Doutorado em Engenharia Florestal) - Universidade Federal do Paraná, Curitiba, 1993.

McCLAUGHERTY C. A.; ABER J. D.; MELILLO J. M. Decomposition dynamics of fine roots in forested ecosystems. Oikos, v.42, n.3, p.378-386, 1985.

McKAY, H. M.; MALCOLM, D. C. A comparison of the fine root component of a pure and a mixed coniferous stand. Canadian Journal Forest Research, v.18, n.11, p.1416-1426, 1988.

MELLO, S. L. M.; GONÇALVES, J. L. M.; OLIVEIRA, L. E. G. Características do sistema radicular em povoamentos de eucaliptos propagados por sementes e estacas. Scientia Forestalis, v. 54, n.1, p.16-26, 1998.

MORGADO, I. F. et al. Nova metodologia de produção de mudas de E. grandis W.Hill ex Maiden utilizando resíduos prensados como substratos. Revista Árvore, v.24, n.1, p.27-33, 2000.
MORONE, M. T.; NORLEDGE, D.; BEADLE, C. L. Root distribution of Eucalyptus nitens and $E$. globules in irrigated and droughted soil. Forest Ecology and Management, v.177, n.2, p.399-407, 2003.

NEVES, J. C. L.; GOMES, J. M.; NOVAIS, R. F. Fertilização mineral de mudas de eucalipto. In: BARROS, N. F.; NOVAIS, R. F. (Eds.) Relação solo-eucalipto. Viçosa, MG: Folha de Viçosa, 1990.330p.

NOVAES, A. B. Avaliação morfofisiológica da qualidade de mudas de Pinus taeda $L$. produzidas em raiz nua e em diferentes tipos de recipientes. 1998. 118p. Tese (Doutorado em Engenharia Florestal) Universidade Federal do Paraná, Curitiba, 1998.

PARVIAINEN, I. V. Future trends for containerized tree seedling production: a literature review. Silva Fennica, v.24, n.1, p.93-103, 1990.

PARVIAINEN, I. V.; TERVO, L. A new approach for production of containerized coniferous seedlings using peat sheets coupled with root pruning. Forestry Supplement, v.62, n.1, p.87-94, 1989.

PERSSON, H. The importance of fine roots in boreal forests. In: BÖHN, W.; KUTCHERA, L.; LINCHTENEGGER, E. (Eds) Root ecology and its practical application. S.I.: s.n., 1992. p.595-608.

POMEROY, L. R. The study of mineral cycling.

Annual Review of Ecology and Systematies, v.1, p.171-190, 1970.

REIS, G. G. et al. Crescimento de Eucalyptus camaldulensis, E. grandis e E. cloeziana sob diferentes níveis de restrição radicular. Revista Árvore, v.13, n.1, p.1-18, 1989.

REIS, G. G. et al. Efeito da poda de raízes de mudas de eucaliptos produzidas em tubetes sobre a arquitetura do sistema radicular e o crescimento no campo. Revista Árvore, v.20, n.2, p.137-145, 1996.

R. Árvore, Viçosa-MG, v.32, n.6, p.1019-1028, 2008 
SCHIAVO J. A.; MARTINS, M. A. Produção de mudas de goiabeira (Psidium guajava 1 .), inoculadas com o fungo micorrízico arbuscular Glomus clarum, em substrato agro-industrial.

Revista Brasileira de Fruticultura, v. 24, n.2, p.519-523, 2002.

SCHMIDT -VOGT, H. Morpho-physiological quality of forest tree seedlings: the present international status of research. In:

SIMPÓSIO INTERNACIONAL DE MÉTODOS DE PRODUÇÃO E CONTROLE DE QUALIDADE DE SEMENTES E MUDAS FLORESTAIS 1984, Curitiba. Métodos de produção e controle de qualidade de sementes e mudas florestais. Curitiba: UFPR/FUPEF, 1984. p.366-378.

SERRANO L. A. L. Sistemas de produção e doses de adubo de liberação lenta na formação de porta-enxerto cítrico (Citrus limonia Osbeck cv.). 2003. 51 p. Dissertação (Mestrado em produção Vegetal) -, Universidade Estadual do Norte Fluminense, Campos dos Goytacazes, 2003.

SINGH, K. P.; SINGH, R. P. Seasonal variations in biomass and energy of small roots in tropical dry deciduous forest, Varanasi, India. Oikos, v.37, n.1, p.88-92, 1981 .
SILVA, J. I. Produção de mudas de café (Coffea canephora) em diferentes recipientes e substratos. 2003. $51 \mathrm{f}$. Dissertação (Mestrado em Produção Vegetal) Universidade Estadual do Norte Fluminense, Campos dos Goytacazes, 2003.

TINUS, R. W.; McDONALD, S. E. How to grown tree seedlings in containers in greenhouses.

Gen. Tech. Rep. RM USDA. For. Serv., v.60, p.1-256, 1979.

TOWNEND, J.; DICKINSON, A. L. A comparison ofrooting environments in containers of different sizes. Plant and Soil, v.175, n.1, p.139-146, 1995.

VOGT, K. A. et al. Overestimaion of net root production a real or imaginary problem? Ecology, v.67, n.2, p.577-579, 1986.

VOGT, K. A.; PERSSON, H. Measuring growth and development of roots. In: LASSOIE, J. P.; HINCKLEY. T. M. (Eds.). Techniques and approaches in forest tree ecophysiology. Boca Raton: CRC Press, 1991. p.447-501.

WITSCHORECK, R.; SCHUMACHER, M. V.; CALDEIRA, M. V. W. Estimativa da biomassa e do comprimento de raízes finas em Eucalyptus urophylla S.T.Blake no Município de Santa MariaRS. Revista Árvore, v.27, n.2, p.177-183, 2003. 